\title{
Competition in the Telephone Equipment Industry: Beyond Telerent
}

In recent years the Federal Communications Commission (FCC) has sought to stimulate competitive entry into the telephone equipment industry ${ }^{1}$ by requiring communications common carriers to interconnect customer-provided terminal equipment with the telephone network. ${ }^{2}$ The common carriers had long resisted interconnection, insisting that customers obtain terminal equipment exclusively from them. ${ }^{3}$ Since the carriers in turn acquired almost all their equipment from their own manufacturing affiliates, ${ }^{4}$ they effectively foreclosed

1. The telephone equipment industry manufactures switching, transmission, and terminal apparatus for use in telephone systems. The first two categories include equipment in the telephone company's central office and the telecommunication links that make up the message distribution network, while terminal equipment operates on the customer's premises. This Note will focus on the production and sale or lease of terminal equipment-items such as the basic handset, teletypewriter equipment, data sets, and switching equipment servicing only one customer. The major types of switching equipment are private branch exchanges (PBXs), which connect individual stations on a customer's premises with one another and with the public telephone system, and kcy telephone systems (KTS), with "lighted multibutton telephones that allow the user to be connected to one of several outside or PBX lines." Systems Applications, INc., Regulatory Policy Changes and the Future of the Independent Telephone Industry 21-22 (1975). See M. Irwin, The Telecommunications Industry 27 (1971); Burkhard \& Clare, User Equipment and Services, in CoMmunication System ENGINEERING HaNdBook (D. Hamsher ed. 1967).

The FCC has also encouraged competition in the provision of private line and satellite communications. See, e.g., Establishment of Domestic Communications Satellite Facilities by Non-Governmental Entities, 35 F.C.C.2d 844, 18 Rad. REG. (P-H) 2D 1631, modified, 38 F.C.C.2d 665, 26 RAD. REG. (P-H) 2D 465 (1972); Microwave Communications, Inc., 18 F.C.C.2d 953, 16 RAD. REG. (P-H) 2D 1037 (1969). For discussion of private-line communications, which involves permanent connections among a limited number of data transmitting stations or basic voice-grade communications terminals, see An Overview of the Domestic Telecommunications Industry and FCC Policies Concerning Terminal Devices and Private Line Services, in Report by the FfDeral Communications Commission on Domestic Telecommunications Policies 7-76 (1976) [hereinafter cited as Overview]. For discussion of satellite communications, see Barrow \& Manelli, Communications Technology-A Forecast of Change (pt. 1), 34 LAw \& Contemp. Prob. 205, 216-24 (1969).

2. For purposes of the Communications Act of 1934, a communications common carrier is any person or corporation offering services for hire "in interstate or foreign communication by wire or radio or in interstate or foreign radio transmission of energy." Communications Act of 1934, $\$ 3(\mathrm{~h}), 47$ U.S.C. $\$ 153(\mathrm{~h})$ (1970). The term encompasses all but the smallest telephone companies.

"Interconnection" is a generic term for linking up equipment or systems with the principal telephone network. In this Note the term will refer to the connection of telephone equipment on the customer's premises.

3. Trebing, Common Carrier Regulation-The Silent Crisis, 34 LAw \& ConTeMp. Prob. 299, 322-23 (1969). See M. Inwiv, supra note I, at 67.

4. The American Telephone \& Telegraph Company (AT\&T) includes Bell Labs, a research unit, the Long Lines Department, which operates most interstate lines, and 23 local operating companies. United States v. AT\&T, 5 TrudE REg. REP. (CCH) (I976-2 


\section{entry into the telecommunications equipment market.5 In North Carolina Utilities Commission v. FCC (Telerent), ${ }^{6}$ the Fourth Circuit upheld the Commission's procompetition policy against attempts by}

Trade Cas.) If 61,163, at 70,245 (D.D.C., Nov. 24, 1976). AT\&T accounts for over $80 \%$ of all telephone service in this country. M. IRwiN, supra note 1 , at 25 . It has been vertically integrated since acquiring Western Electric Co. as its manufacturing affiliate in 1882. Trebing, supra note 3, at 303. The second largest common carrier, General Telephone \&: Electronics Corp. (GT\&E), has acquired several manufacturing affiliates. Irwin \& McKee, Vertical Integration and the Communication Equipment Industry: Alternatives for Public Policy, 53 Cornell L. REv. 446, 447 (1968). See Irwin, Vertical Integration and the Communications Industry: Separation of Western Electric and AT\&T?, 3 ANTITRUsT L. \& EcoN. REv, Fall 1969, at 125, 131. Three studies by the industry completed since 1973 suggest that the manufacturing subsidiaries of the carriers sell annually over $90 \%$ of the PBXs and key systems in the nation. Economic Implications and Interrelationships Arising From Policies and Practices Relating to Customer Interconnection, Jurisdictional Separations, and Rate Structures, FCC Docket No. 20003, app. C at 2 (Sept. 23, 1976) [hereinafter cited as Economic Implications].

Vertical integration of regulated firms has been criticized for permitting the extension of a legal monopoly to nonregulated markets, much as illegal "tie-in" sales of patented articles permit the spreading of the legal patent monopoly to other markets. Irwin \& McKee, supra at 446. Recognizing these dangers, the FCC has forced the common carriers to set up independent affiliates in data processing markets and has limited business dealings between the carriers and such affiliates. 47 C.F.R. $\$ 64.702$ (1976). This policy was approved in GTE Serv. Corp. v. FCC, 474 F.2d 724 (2d Cir. 1973). Similarly, the Commission has prevented the carriers from operating community-antenna television systems (CATV) in their telephone service areas. 47 C.F.R. $\$ \S 63.54-.57$ (1976). The Fifth Circuit upheld this regulation in General Tel. Co. v. United States, 449 F.2d 846 (5th Cir. 1971).

There have been a number of attempts to force AT\&T to divest itself of Western Electric, beginning with an unsuccessful antitrust suit by the Justice Department in 1949. See 45 CoRnell L.Q. 88 (1959). The FCC recently declined to act on the request by the FCC trial staff that AT\&:T and Western Electric be separated. Wall St. J., Feb. 24, 1977 , at 2, col. 2. The Commission's action followed the preliminary recommendation of an administrative law judge. AT\&T (The Associated Bell System Companies), FCC Docket No. 19129 (July 14, 1976) [hereinafter cited as Divestiture Proceedings]. In addition, in its pending suit against AT\&T the Justice Department is again asking that Western Electric be split off from the Bell System. United States v. AT\&:T, Civ. No. 74-1698 (D.D.C., filed Nov. 20, 1974).

5. The FCC ordered the common carriers to adopt liberal interconnection policies to permit direct interconnection of all equipment meeting technical requirements. Proposals for New or Revised Classes of Interstate and Foreign Message Toll Tel. Serv. (MTS) and Wide Area Tel. Serv. (WATS), 56 F.C.C.2d 593 (1975), modified, 58 F.C.C.2d 736 (1976). This policy is currently being challenged in the courts. North Carolina Utils. Comm'n v. FCC, Civ. No. 76-1002 (4th Cir., filed Jan. 2, 1976). The FCC policy also could be nullified by legislation advocated by the common carriers and endorsed by over 200 members of Congress. S. 3192, 94th Cong., 2d Sess. (1976); H.R. 12816, 94th Cong., 2d Sess. (1976). The felicitously titled "Consumer Communications Reform Act of 1976" was introduced at the request of the common carriers. It would "reaffirm" congressional intent to afford the states complete authority over terminal equipment, including authority over devices used partly in interstate service. The legislation would also restrict the FCC's ability to permit competition between "specialized common carriers" and established telephone common carriers in the provision of private-line communication.

The New York Public Service Commission is currently considering adoption of a liberal interconnection policy that would apply to all carriers in the state. N.Y. Times, Feb. 15, 1977, at 1, col. 5 .

6. 537 F.2d 787 (4th Cir. 1976), cert. denied, 45 U.S.L.W. 3427 (U.S. Dec. 14, 1976). 
state regulatory agencies to block interconnection. The court ruled that the FCC, not the states, had jurisdiction over the telephone companies' interconnection policy.

The Telerent ruling, however, does not end the controversy over competition in the equipment industry. This Note will show that the common carriers can still thwart competition by manipulating intrastate telephone rates, which are beyond the reach of the FCC, in order to subsidize equipment prices and thus gain an advantage over their competitors. In this analysis, subsidization refers to the failure of a regulated firm to recover its long-run marginal costs ${ }^{7}$ on a particular service. $^{8}$ After examining both the jurisdictional and economic aspects of Telerent, this Note will argue that the decision delimits a jurisdictional structure that will frustrate any FCG attempts to prevent subsidization. To ensure effective competition in the equipment industry, the FCG should take administrative action to aid the state regulatory agencies in monitoring subsidization. In addition, Congress should grant the FCC limited authority to review the impact on competition of intrastate telephone rates.

\section{The Telerent Litigation}

Telerent involved two sets of issues. The Fourth Circuit decided the jurisdictional question, which was the focus of the litigation, but never explicitly considered the underlying economic concerns.

\section{A. The Jurisdictional Dispute}

Since early in this century, the telephone industry has been regulated on both the state and federal levels. ${ }^{9}$ With much interstate and intrastate telecommunications service provided over the same trans-

7. For discussion of long-run marginal cost, sce pp. 555-58 \& notes 75-77, $88-89$ infra.

8. Obviously, many definitions of subsidization are possible, depending on the costs that one decides should be reflected in price. As indicated at pp. 556-5S infra, this Note adopts a long-run marginal-cost definition because it best capturcs efficiency considerations. For discussions of the subsidization problem, see Baumol, Eckstein \& Kahn, Competition and Monopoly in Telecommunications Services (1970), reprinted in The Industrial Reorganization Act: Hearings on S. 1167 Before the Subcomm. on Antitrust and Monopoly of the Senate Comm. on the Judiciary, 93d Cong., lst Sess., pt. 2, at 1343-41 (1973) [hearings hereinafter cited as Industrial Reorganization Hearings]; Posner, Taxation by Regulation, 2 BeLL J. ECON. \& MGMT. Scr. 22, 24-27 (1971).

9. Federal regulation by the Interstate Commerce Commission (ICC) began in 1910, Gabel, The Early Competitive Era in Telephone Communication, 1893-1920, 34 Law \& Contenp. ProB. 340, 355-58 (1969), while state regulation started in Wisconsin in 1907, 1907 Wis. Laws, ch. 499. 
mission and switching facilities, the dual regulatory system has generated conflict between state and federal regulatory authorities. ${ }^{10}$ That conflict resulted in the Telerent litigation, which centered on the FCG's authority to preempt state regulation of the telephone common carriers' interconnection policies. ${ }^{11}$

The FCG's efforts to promote competition in the telephone equipment industry began with its 1968 Carterfone decision, which held that a carrier could not refuse to interconnect a customer-provided mobile radio-telephone device. ${ }^{12}$ After Carterfone, the carriers permitted interconnection of customer-provided equipment only when a carrier-provided "interface" device was also installed to protect the

10. Much of this conflict has centered on the issue of service rates. Both federal and state agencies use rate-of-return regulation to control the carriers' pricing. Compare, e.g., AT\&T, 9 F.C.C.2d 30 (1967) with Chesapeake \& Potomac Tel. Co., 10 PuB. U. REP. (PUR) 4 TH 255 (Va. State Corp. Comm'n 1975). To calculate the allowed earnings of the utility, the agency multiplies the fair value of the utility's net property investment devoted to the provision of telecommunications service (the rate base) by a "reasonable" rate of return. The permissible rate of return is an amalgam of the cost of borrowed capital and a reasonable return on the regulated firm's equity. The regulator also determines the firm's operating cxpenses and combines that figure with the allowed earnings to arrive at the firm's revenue requirement. Rates are then set to meet this revenue requirement. Cunningham, The Anatomy of a Utility Rate Case, in THE NEw Economics of Regulited Industries 21, 28-36, 40-46 (J. Haring ed. 1968).

Since intrastate and interstate telephone messages often use the same equipment, federal and state regulators face the recurring problem of "separating" the costs of such equipment between AT\&:T's Long Lines Department, which handles Iong-distance, principally interstate traffic, and the local telephone companies, whose main business is intrastate communications. The separations process is crucial to establishing the rate bases on which the intrastate and interstate rates are calculated. The more capital equipment cost assigned to the interstate rate base, the higher the carrier's permissible interstate rates and, assuming coordination between state and federal authorities, the lower the permissible intrastate rates will be. In their efforts to keep service rates low within their respective jurisdictions, the state commissions and the FCC have frequently locked horns over proper separations procedures. Spychalski, The NARUC: Contributor to Effective Regulation? A Retrospective and Prospective Critique, in A CRITIQue of ADamiststrative Regulation of Public Utilities 89, 106-12 (W. Samuels \& H. Trebing eds. 1972).

11. 537 F.2d at 790-95. See Sherdon v. Dann, 193 Neb. $768,773-78,229$ N.W.2d 531, 534-37 (1975). For discussion of state regulatory attitudes, see pp. 552-53 \& notes 64-68 infra.

12. 13 F.C.C.2d 420, 13 Riv. REg. (P-H) 2d 597, aff'd, 14 F.C.C.2d 571, 14 RAd. Reg. (P-H) 2D 185 (1968). The Carterfone device linked a telephone receiver to a radio, permitting communication between a caller and someone miles away from the receiver. When the common carriers refused to permit use of the device, the manufacturer sued them for antitrust violations. Both the district and circuit courts held that the FCG's primary jurisdiction over interconnection policy barred judicial consideration of the antitrust claim prior to Commission review of the carriers' interconnection policy. Carter v. AT\&T, 250 F. Supp. 188 (N.D. Tex.), aff'd, 365 F.2d 486 (5th Cir. 1966), cert. denied, 385 U.S. 1008 (1967). The FCC concluded that the Carterfone device met an unsatisfied market demand and would not have adverse engineering cffects on the telephone system. 13 F.C.C.2d at 423, 13 RAd. REg. (P-H) 2D at 601. Accordingly, the Commission ordered the carriers to permit interconnection of the device and to revise their general interconnection policy. Id. 
telephone system from disruption due to faulty equipment. ${ }^{13}$ The growth of competition after Carterfone was slow, ${ }^{14}$ but by 1974 the FCC's policy had been sufficiently successful to prompt preliminary rulings by the North Carolina Utilities Commission and the Nebraska Utilities Commission banning interconnection of customer-provided equipment. ${ }^{15}$ The North Carolina commission contended that the present phone network had performed satisfactorily without interconnection. ${ }^{16}$ The Nebraska commission relied on an opinion by the state attorney general that the FCC's jurisdiction did not extend to terminal equipment. ${ }^{17}$ In response, the FCC reasserted its jurisdiction over an interstate carrier's interconnection policy. The Commission argued that since telephone equipment "is used in common and indivisibly for all local and long distance telephone calls," the state interconnection rulings covered interstate as well as intrastate service, conflicting with the FCC's plenary authority over the nationwide telephone network. ${ }^{18}$ The states challenged FCG jurisdiction on the basis of $\$ 2(b)$

\section{See note 33 infra.}

Without approving the carriers' modified interconnection policy, the FCC permitted it to take effect. AT\&T, 15 F.C.C.2d 605, 611, 15 RAD. Rec. (P-H) 2D 91, 97 (1968). Proponents of interconnection claimed that interfaces were unnecessary and that the carricrs had delayed production of interfaces to deter customers from providing their own equipment. Industrial Reorganization Hearings, supra note 8, pt. 5, at 2897, 2900 (1974) (letter of W. Jacobsen, TeleResources, Inc.), 2778-91 (affidavits of employees of Arcata Communications, Inc.). In 1975 the FCC concluded that interface devices were unnecessary and moved to ensure the technical integrity of the national telephone network by instituting a national certification scheme. Proposals for New or Revised Classes of Interstate and Foreign Message Toll Tel. Serv. (MTS) and Wide Area Tel. Serv. (WATS), 56 F.C.C.2d 593 (1975), modified, 58 F.C.C.2d 736 (1976).

14. Economic Implications, supra note 4 , at 61 .

15. North Carolina Utils. Comm'n, No. P-100, Sub 31 (undated), reprinted in Brief for Respondents at 3a-8a, North Carolina Utils. Comm'n v. FCC, 537 F.2d 787 (4th Cir. 1976) [hereinafter cited as North Carolina Challenge]; Sherdon v. Ben Franklin Hotel, No. 1078 (Neb. Pub. Serv. Comm'n Apr. 15, 1974), rev'd sub nom. Sherdon v. Dann, 193 Neb. 768, 229 N.W.2d 531 (1975), reprinted in Brief for Respondents at 13a-17a, North Carolina Utils. Comm'n v. FCC, 537 F.2d 787 (4th Cir. 1976) [hereinafter cited as Nebraska Challenge].

16. North Carolina Challenge, supra note 15 , at $4 \mathrm{a}$.

17. 537 F.2d at 790. In the action before the Nebraska commission, interconmection of a customer-provided switchboard system in a motel was terminated under NEB. REV. Star. \$ 75-604 (1971), which bars interconnection of telephone systems without prior commission approval. Nebraska Challenge, supra note 15, at $15 \mathrm{a}$.

18. Telerent Leasing Corp., 45 F.C.C.2d 204, 215, 29 RAD. REg. (P-H) 2D 553, 566 (1974), aff'd sub nom. North Carolina Utils. Comm'n v. FCC, 537 F.2d 787 (4th Cir. 1976); Bricf for Respondents at 25-31, North Carolina Utils. Comm'n v. FCC, 537 F.2d 787 (4th Cir. 1976). The FCC based its authority on its mandate under the Communications Act of 1934, 47 U.S.C. $\$ \S 201-205$ (1970), to ensure that carriers follow "just and reasonable" practices. The Commission interpreted that mandate in its Telerent ruling:

[T] he Commission's powers to regulate interstate and foreign communications services are comprehensive and pervasive and embrace the terms and conditions under which customers shall be reasonably permitted to use their own equipment in connection with such services.

45 F.C.C.2d at 217. 


\section{of the Communications Act, which denies the FGG authority over intrastate communications. ${ }^{19}$}

A divided court of appeals found that $\S 2(\mathrm{~b})$ preserved exclusive state control only over matters "that in their nature and effect are separable from and do not substantially affect the conduct or development of interstate communications." 20 The majority accepted the Commission's argument that since almost all telephone equipment is used for communications both within and across state boundaries, ${ }^{21}$ equipment policies necessarily affect interstate communication. The FCC had thus properly exercised its authority. ${ }^{22}$ The court also em-

19. Communications Act of 1934 2(b), 47 U.S.C. $\$$ 152(b) (1970) provides:

[N]othing in this chapter shall be construed to apply or to give the Commission jurisdiction with respect to (I) charges, classifications, practices, services, facilities, or regulations for or in connection with intrastate communications service by wire or radio of any carrier ....

For arguments of AT\& $\mathrm{T}$ and the state commissions on the interpretation of this section, see Brief for Petitioners at 26.33, North Carolina Utils. Comm'n v. FCC, 537 F.2d 787 (4th Cir. 1976).

20. 537 F.2d at 793 .

21. Telerent Leasing Corp., 45 F.C.C.2d 204, 214-15, 29 RAd. Reg. (P-H) 2d 553, 566 (1974). For example, the basic telephone handset can be used for local or interstate calls.

22. Because the legislative history is ambiguous, the court appropriately deferred to the agency's interpretation of the statute. See United States v. Southwestern Cable Co., 392 U.S. 157, 177-78 (1968). There is evidence that Congress did not intend to restrict FCC authority where federal and state concerns overlapped. Section 2(b) first appeared in an amendment by Senator Clark to the Senate version of the Communications Act, providing that "small, independent telephone companies" would not be subjected to federal regulation. Senator Dill, floor manager of the bill, accepted the amendment because "its only purpose is to accomplish that which we have tried to do throughout the bill, that is, to protect the independent companies." 78 CoNG. Rec. 8847 (1934). Clearly, both men saw the section as preventing federal regulation of small "Mom and Pop" telcphone companies, not as granting to the states exclusive power over all intrastate operations of common carriers. See id. at 10313 (Rep. Rayburn); Sherdon v. Dann, 193 Neb. 768, 229 N.W.2d 531 (1975) (federal primacy over telephone cquipment); Western Union Tel. Co. v. State, 207 Ga. 675, 682, 63 S.E.2d 878, 883 (1951) (under \$ 2(b) FCC should have jurisdiction over all equipment used in both intrastate and interstate service).

The petitioners in Telerent maintained that $\$ 2(\mathrm{~b})$ was intended to foreclose FCC authority over any intrastate activities. Brief for Petitioners at 20-27, North Carolina Utils. Comm'n v. FCC, 537 F.2d 787 (4th Cir. 1976). The strongest support for this position appears in SEN. REP. No. 781, 73d Cong., $2 \mathrm{~d}$ Sess. 3 (1934), explaining that under $\$ 2(b)$, "the Act is applicable ... to interstate and foreign communications, but reserves to the States exclusive jurisdiction over intrastate telephone and telegraph communications." Compare H.R. REP. No. 1850, 73d Cong., $2 d$ Sess. 4 (1934).

Judge Widener, dissenting in Telerent, concluded that $\$ 221$ (b) of the Communications Act, 47 U.S.C. $\$ 221$ (b) (1970), barred the FCC from regulating equipment used for interstate and intrastate service. 537 F.2d at 796-99. The provision prohibits the FCC from exercising jurisdiction over local exchanges "even though a portion of such exchange service constitutes interstate or foreign communication, in any case where such matters are subject to regulation by a State commission or by local governmental authority." Id. at 797 (emphasis added). Section 3(r) of the Communications Act, 47 U.S.C. $\$ 153(r)$ (1970), defines telephone exchange service as "within a telephone exchange, or within a connected system of telephone exchanges ... operated to furnish . . . service of the character ordinarily furnished by a single exchange." The Telerent majority rejected Judge Widener's position, pointing out that $\$ 221(b)$ only grants jurisdiction to the 
phasized that the FCG had consistently asserted jurisdiction over telephone equipment used jointly for interstate and intrastate service, ${ }^{23}$ often with the tacit approval of the courts. ${ }^{24}$ Finally, the court noted, Congress provided for referral of such joint jurisdiction problems to a panel of state utility and FCC commissioners. ${ }^{25}$ If $\$ 2(\mathrm{~b})$ barred FCC jurisdiction over all matters involving intrastate service, no joint jurisdiction problems could ever arise. ${ }^{26}$

The FCC's control over equipment, though, is not unlimited. Section 2(b) places intrastate rates within the exclusive domain of the states, and although the issue was not in dispute in Telerent, the court acknowledged that exclusivity. ${ }^{27}$ Since terminal equipment is leased by local carriers, rates charged by the local telephone companies for that equipment-like rates for local telephone service-will still fall within the authority of the state commissions rather than the FCC.

\section{B. Economic Issues}

Beneath the jurisdictional wrangling of Telerent lay the question of the future structure of the equipment industry. The FCC asserted

states over local exchange service that straddles state lines, as in the Washington, D.C./ Virginia/Maryland area. 537 F.2d at 795. See SEN. REP. No. 781, 73d Cong., 2d Sess. 5 (1934); H.R. ReP. No. 1850, 73d Cong., 2d Sess. 7 (1934) (Section 221(b) "will enable [state] commissions, where authorized to do so, to regulate exchange services in metropolitan areas overlapping State lines.")

23. $537 \mathrm{~F} .2 \mathrm{~d}$ at 794-95. The FCC asserted authority over telephone equipment policy in United States Dep't of Defense v. General Tel. Co., 38 F.C.C.2d 803, 26 RaD. REg. (P-H) 2D 245, modified, 39 F.C.C.2d 843 (1973); Carterfone, 14 F.C.C.2d 571, 14 RAD. REG. (P-H) 2D 185 (1968); AT\&T-TWX, 38 F.C.C. 1127 (1965); AT\&T-Railroad Interconnection, 32 F.C.C. 337 (1962); Hush-A-Phone Corp. v. AT\&T, 22 F.C.C. 112 (1957); Katz v. AT\&T, 8 RAD. REg. (P-H) 919 (1953); and Use of Recording Devices, 11 F.C.C. 1033 (1947). But see Doniphan Tel. Co. v. AT\&T, 34 F.C.C. 949 (1963), adopting opinion in 34 F.C.C. 950 (1962) (FCC lacked jurisdiction over local Missouri telephone company's request that its interconnection with Bell System be altered); Jordaphone Corp. of America v. AT\&T, 18 F.C.C. 644 (1954) (since automatic answering devices would handle mostly intrastate calls, FCG need not act to protect interstate service).

24. The courts deferred to the FCC's primary jurisdiction over telecommunications equipment in Carter v. AT\&T, 250 F. Supp. 188 (N.D. Tex.), aff'd, 365 F.2d 486 (5th Cir. 1966), cert. denied, 385 U.S. 1008 (1967). See note 12 supra. Similarly the FCC's jurisdiction over automatic dialing devices was acknowledged in Macom Prods. Corp. v. AT\&T, 359 F. Supp. 973, 977 (C.D. Cal. 1973). In Hush-A-Phone Corp. v. FCC, 238 F.2d 266, 267 (D.C. Cir. 1956), the court, in rejecting an FCC finding that a telephone speaker guard endangered the integrity of the phone network, implicitly conceded the FCC's authority over such equipment.

25. 537 F.2d at 795 . Under 47 U.S.C. $\$ 410$ (Supp. V 1975) the FCC may convene such "joint boards" at its discretion.

26. Since the enactment of 47 U.S.C. $\S 410$ (c) (Supp. V 1975) in 1971, Joint Boards have been used to handle the problem of separating interstate toll revenues between local operating companies and AT\&T's Long Lines Department. See note 10 supra.

27. 537 F.2d at 793 n.6 ("Of course, rate making typifies those activities of the telephone industry which lend themselves to practical separation of the local from the interstate in such a way that local regulation of one does not interfere with national regulation of the other.") 
jurisdiction in order to promote competition in an industry in which the carriers' vertical integration has stifled competitive entry. The states, on the other hand, claimed jurisdiction in order to block interconnection and restore a noncompetitive situation. The FCC policy has greater merit.

A telephone company's local transmission and switching system constitutes a natural monopoly. Like most natural monopolies, it has significant economies of scale ${ }^{28}$ and a distribution system entailing physical connection between customer and supplier, which cannot be duplicated economically. ${ }^{29}$ Regulation permits realization of the efficiencies of the natural telephone monopoly but prevents the regulated telephone company from "raising prices to levels which exploit its monopoly position." 30 The efficiency rationale for regulation, however, extends only as far as the natural monopoly. ${ }^{31}$ It does not carry over into the telephone equipment industry, which, like most manufacturing industries, does not have the scale economies or distribution system characteristic of a natural monopoly. ${ }^{32}$ Telephone equipment in many ways resembles electrical appliances that can be plugged into

28. The critical characteristic of natural monopoly has been defined as "an inherent tendency to decreasing unit costs over the entire extent of the market." 2 A. KAHN, THE Economics of Regulation 119 (1970). See F. Scherer, Industrial Market Structure and Economic Performance 520 (1970) (in natural monopoly "long-run unit cost function declines continuously out to a scale of output which saturates potential market demand").

Kahn argues that although telephone service exhibits increasing costs if the output is measured in terms of the number of customers, the more accurate approach recognizes that the addition of each new subscriber improves the quality of telephone service for all subscribers by increasing the number of stations that can be reached. Thus, local telephone service is a natural monopoly under the decreasing-cost criterion because the costs of adding an additional subscriber are more than offset by the consequent benefits conferred on other telephone users. 2 A. KAHN, supra, at 123-24.

29. As Kahn observes:

[I]f there were two telephone systems serving a community, each subscriber would have to have two telephone instruments, two lines into his home, two bills if he wanted to be able to call everyone else. . . . [M]onopoly is . . . natural because one company can serve any given number of subscribers (for examplc, all in a community) at lower cost than two.

2 A. KAHN, supra note 28, at 123 (footnotes omitted; emphasis in original). See J. Bonbright, Principles of Public Utility Rates 4-5, $12-13$ (1961).

30. F. SCHERER, supra note 28 , at 520 .

31. 2 A. KAHN, supra note 28 , at $151-52$ ("The economic ideal would clearly be for the area of natural monopoly to be defined as narrowly as possible. . . .")

In Cantor v. Detroit Edison Co., 96 S. Ct. 3110,3119 (1976), the Supreme Court asserted that the competitive standards of the antitrust laws can be applied to nonmonopoly aspects of an electric utility's business and implicitly recognized the validity of confining regulation to natural monopolies.

32. Hearings on H.R. 12323 Before the Subcomm. on Communications of the House Comm. on Interstate and Foreign Commerce, 94th Cong., 2d Sess. 16-17 (1976) (A. Kahn, Chairman, N.Y. Pub. Serv. Comm'n); Industrial Reorganization Hearings, supra note 8 , pt. 6, at 3841 (1974) (Clay Whitehead, Director, Office of Telecommunications Policy); see Turner, The Role of Antitrust Policy in the Communications Industry, 13 ANTITrust BuLl. 873, 877 (1968); note 28 supra. 
the electric power system's terminals in homes and businesses. As long as technical specifications protect the network from dangers posed by interconnection of defective or incompatible equipment, the telephone subscriber should be free to purchase equipment on the open market. ${ }^{33}$

A policy confining regulation to natural monopoly aspects of the telephone industry would promote lower prices, greater product diversity, and a higher rate of innovation than one limiting all telecommunications submarkets to one or a small number of suppliers. ${ }^{34}$ Even though the competitive equipment industry is still in its infancy, prices have declined for some types of equipment and the variety of

33. AT\&T has invoked the specter of technical damage to the transmission and switcliing system in opposing introduction of a broad range of equipment by suppliers not affiliated with the common carriers. Among the possible dangers to "system integrity" posed by defective equipment might be erratic voltage generation on telephone lines, improper network control signaling, and poor service due to distortion of signals. Brief of Petitioners at 69-70, North Carolina Utils. Comm'n v. FCC, No. 76-1002 (4th Cir., filed Jan. 2, 1976).

Historically, however, the carriers have overstated their argument. They have failed in attempts to use the system-integrity issue to block competitors from supplying plastic covers for telephone directories, State ex rel. Utils. Comm'n v. National Merchandising Corp., 288 N.C. 715, 723-24, 220 S.E.2d 304, 309-10 (1975), and cup-shaped telephone speaker guards designed to provide greater privacy, Hush-A-Phone Corp. v. FCC, 238 F.2d 266, 268-69 (D.C. Cir. 1956).

In deference to the system-integrity argument, the FCC, after Carterfone, permitted AT\&T to require protective interface devices on all customer-provided equipment. AT\&T, 15 F.C.C.2d 605, 15 RAD. REG. (P-H) 2D 91 (1968). An FCC-sponsored study suggested that a possible alternative to interfaces might be "enforced certification [of the reliability] of user-supplied equipment and personnel." National Academy of Sciences, A Technical Analysis of The Common Carrier/User Interconnections Area 56 (1970), reprinted in Affidavit of Scott Shepherd at Attachment K, II Appendix Annexed to Defendants' Memorandum Submitted Pursuant to the Court's Order of Feb. 27, 1975, United States v. AT\&T, Civ. No. 74-1698 (D.D.C. filed Nov. 20, 1974). Five years later, the FCC abandoned the interface requirement in favor of direct interconnection of certified equipment. Proposals for New or Revised Classes of Interstate and Foreign Message Toll Tel. Serv. (MTS) and Wide Area Tel. Serv. (WATS), 56 F.C.C.2d 593, 598-99 (1975), modificd, 58 F.C.C.2d 736 (1976). The FCC reasoned that many "special" entities, such as other utilities and government agencies, had directly interconnected their equipment for years without harm to the system. The FCG also noted that many non-Bell carriers using nonBell equipment had interconnected with the Bell network without difficulty. Indeed, telephone systems in foreign nations have long followed such liberal interconnection policies. See Stanford Resenrch Institute, Relort Re INSight into Telephone INTERCONNECTION INDUSTRY (1970), reprinted in Industrial Reorganization Hearings, supra note 8, pt. 6, at 4654, 467I-73 (1974); Rescarch Institute of Telecommunications and Economics, Customer-Owned Equipment Interconnection in Japan, reprinted in Industrial Reorganization Hearings, supra note 8, pt. 2, at 1089-95 (1973).

The FCC's certification program has been suspended pending the outcome of a court challenge. North Carolina Utils. Comm'n v. FCC, Civ. No. 76-1002 (4th Cir. Apr. 29, 1976) (order granting injunction).

34. Baumol, Eckstein \& Kahn, supra note 8, at 1333-47. See Rochester Tel. Corp., 94 PUB. U. REP. (PUR) 3b 370, 377 (N.Y. Pub. Serv. Comm'n 1972) (approving liberalization of interconnection policy on grounds that "freer competition will afford subscribers a wider choice of equipment . . , will stimulate innovation ..., and will promote reductions in cost"). 
products offered has broadened..$^{35}$ And despite the adequate innovation performance of the Bell System, competition is likely to provide a stronger incentive to innovate. ${ }^{36}$ An unregulated firm can exploit any new product or improved efficiency without the ceiling on profits imposed by regulation. ${ }^{37}$ Further, unlike the regulated company, the competitive firm that sells rather than leases equipment is less tied to a particular technology and is thus not deterred from innovation. ${ }^{38}$ Finally, a competitive market provides a valuable diversity of approaches to technical and economic problems. ${ }^{39}$

Opponents of the FCC's interconnection policy have presented no substantial argument denying that interconnection should enhance

35. For example, the pre-Carterfone price of carrier-provided answering machines was approximately $\$ 500$. By 1976 , after a period of high inflation, competition had driven the price down to $\$ 410$. Overview, supra note 1, at 67-68. Further, the Southern New England Telephone Company has reported saving \$2.1 million in one year by purchasing equipment from non-Bell suppliers. Divestiture Proceedings, supra note 4 , at 185 . The New York Telephone Company achieved a higher return on its equipment-leasing business when it switched from Western Electric PBXs to similar equipment manufactured by Nippon Electric. Id. at 190. See id. at 192, 512 n.167; Proposals for New or Revised Classes of Interstate and Foreign Message Toll Tel. Serv. (MTS) and Wide Area Tel. Serv. (WATS), 35 F.C.C.2d 539, 542 (1972) (FCC claims that Carterfone opened industry to greater innovation and product variety).

New equipment available after Carterfone includes a telephone terminal specially designed for the deaf, developed in the mid-1960s by a California doctor. The carriers have never marketed the device, but independent firms have sold more than 20,000. Brief for Respondents at 91-92, North Carolina Utils. Comm'n v. FCC, Civ. No. 76-1002 (4th Cir., filed Aug. 16, 1976) (reprinting letter from FCG Chairman Wiley to Rep. Van Deerlin (May 25, 1976)).

36. 2 A. KAHN, supra note 28, at 149; Shepherd, The Competitive Margin in Communications, in Technological Change in Regulated Industries 86, $117-18$ (W. Capron ed. 1971). See generally Irwin \& McKee, supra note 4, at $452-57$ (case studies criticizing Bell's innovation performance in monopoly markets).

37. Even though Western Electric is not subject to direct regulatory control, there is an increasing trend among state commissions to regulate it indirectly by excluding from a carrier's rate base any part of the price of Western Electric equipment that the commissions deem excessive. See, e.g., Pacific Tel. \& Tel. Co., 53 Pub. U. ReP. (PUR) 3D 513 (Cal. Pub. Utils. Comm'n 1964), aff'd sub nom. Pacific Tel. \& Tel. Co. v. Public Utils. Comm'n, 62 Cal. 2d 634, 401 P.2d 353, 44 Cal. Rptr. I (1965); New York Tel. Co., 2 Pub. U. ReP. (PUR) 4Th I (N.Y. Pub. Serv, Comm'n 1973); Pacific Northwest Bell Tel. Co. v. Sabin, 534 P.2d 984 (Or. App. 1975); Note, Treatment of Affiliated Transactions in Utility Rate Making: Western Electric Company and the Bell System, 56 B.U. L. REv. 558, 568.71 (1976).

38. Shepherd, supra note 36, at 108. Although Western Electric sells its equipment to the carriers, the carriers lease equipment to their customers. In the absence of competition, there is insufficient demand by Western Electric's primary customers (the carriers) for innovation, and concomitantly, less incentive for Western Electric to innovate.

39. Posner, Natural Monopoly and Its Regulation, 21 STAN. L. REv. 548, 582 (1969) (since research and development involve trial and error, variety of approaches is more valuable than one large research effort). The FCC articulated similar views in Domestic Communications Satellite Facilities, 35 F.C.C.2d 844, 847, 24 RAD. Reg. (P.H) 2D 1942, 1946 (1972). See F. Scherer, supra note 28, at 363-78 (after reviewing empirical literature on innovation and market structure concludes that multifirm structure is optimal for innovation). 
both product variety and innovation. ${ }^{40}$ Their case against liberal interconnection hinges on two contentions. First, they assert, although some aspects of the industry may not be part of a natural monopoly, the nation's entire telecommunications network must be centrally organized and planned in order to develop the full potential of the system. ${ }^{41}$ In addition, interconnection opponents contend that because the common carriers subsidize basic telephone exchange servicet: with revenues from the leasing of PBXs, key systems and extension phones, ${ }^{43}$ competition in the provision of terminal equipment will significantly increase the price of exchange service. ${ }^{44}$ These predictions have been criticized for methodological shortcomings, however, and for the disparity between the enormity of the predicted loss and the fractional size of the competitive sectors of the telecommunications

40. The president of Bell Telephone Laboratories asserted before a congressional subcommittee in 1974 that the regulation of telecommunications has facilitated superior innovation performance in the industry, in contrast to the innovation record in the competitive garment industry. Industrial Reorganization Hearings, supra note 8, pt. 6, at 4347, 4351-52 (1974). The relative potentials for innovation in the high-technology communications industry compared to the labor-intensive clothing industry render the comparison patently absurd. The Bell spokesman further undercut his point by stressing that the major recent innovation in the garment industry-synthetic fiber-was developed by the chemical industry. But that industry, too, is unregulated. The National Academy of Sciences concluded that interconnection "should not significantly impede innovation by the carriers and may promote innovation by users." National Academy of Sciences, supra note 33 , at 12 .

41. Domestic Common Carrier Regulation: Hearings on H.R. 7047 Before the Subcomm. on Communications of the House Comm. on Interstate and Foreign Commerce, 94th Cong., 1st Sess. 222 (1975) (statement of E.B. Crosland, senior vice-president, AT\&T) [hereinafter cited as Carrier Regulation Hearings]. The panel of experts that wrote the 1970 National Academy of Sciences report, however, concluded that interconnection would not hamper the technical or innovation performance of the telecommunications industry. National Academy of Sciences, supra note 33, at 3 .

42. An "exchange" is "a unit . . . for the administration of communication service in a specified area which usually embraces a city, town, or village and its environs." J. Martin, Telecommunications and The Computer 444 (1969).

43. Davidson \& Kraus, New Approaches to Telephone Regulation by State Commissions, Pub. Utils. ForT., Jan. 17, 1974, at 36; Moulton, Monopoly and Competition Issues Facing the Communications Industries, 13 ANTrTrust Bull. 889, 892 (1968); National Ass'n of Regulatory Util. Comm'rs (NARUC), Report After Investigation (May 15, 1974), reprinted in Industrial Reorganization Hearings, supra note 8 , pt. 6, at 4460, 4505-19 (1974) [report hereinafter cited as NARUC Report]; Systems APpliCATIONs, INC., supra note 1 , at $25-31$.

44. An AT\&:T study estimated that as a result of competition in equipment and private-line communications, average residential subscriber charges would increase more than $70 \%$, from $\$ 7.85$ a month to $\$ 13.70$. Carrier Regulation Hearings, supra note 41 , at 263-64 (statement of Prof. E.V. Rostow). NARUC estimated that competition in terminal equipment markets would reduce the subsidy to basic exchange service by a total of $\$ 2.4$ billion between 1975 and 1980. NARUC Report, supra note 43, at 4515 .

Both NARUG and the United States Independent Telephone Association have also expressed dismay that under current separations practices (see note 10 supra) the local carriers may lose part of their share of interstate revenues as the result of interconnection. NARUC Report, supra note 43, at 4508-10; Systems Applications, Inc., supra note 1, at 25. But see Industrial Reorganization Hearings, supra note 8, pt. 6, at 4615 (1974) (John Cosgrove, Tate Communications). 
industry. ${ }^{45}$ Indeed, there is evidence that, contrary to Bell's claims, residential phone service subsidizes equipment services. ${ }^{46}$

Even assuming that Bell's claims are accurate, such subsidization is inefficient and thus costly to the consumer. ${ }^{47}$ The monopoly profits claimed by Bell in the equipment industry, which has been insulated from competitive entry, indicate that resources have been diverted from that area. ${ }^{48}$ The low, subsidized price for monopoly services induces consumers to use more of those services than they would if charged prices reflecting the total costs of those services. ${ }^{49}$ Moreover,

45. John Eger, then Acting Director of the Office of Telecommunications Policy, called the Bell estimates "grossly exaggerated," noting that the estimates are based on an assumption-uncertain at best-that AT\&T will lose large parts of both competitive and monopoly service revenues, and that the figures do not take account of decreased costs accompanying any such decline in business. 122 Cong. Rec. E3113 (daily ed. June 4, 1976).

The NARUC study on interconnection (cited at note 43 supra), which largely echoed Bell's dire prediction, has been criticized for assuming that equipment rates prior to competition were higher than required to cover costs, and for failing to deduct cost reductions that would accompany any revenue losses. Industrial Reorganization Hearings, supra note 8, pt. 6, at 4613-15 (1974) (John Cosgrorc, Tate Communications).

In 1975, independent telephone equipment companies accounted for only $0.4 \%$ of all equipment sales. All competitive telecommunications markets represented less than $12 \%$ of the total revenue of the Bell System, and only $\$ 4$ billion of the $\$ 35$ billion of telephone industry revenues in 1975. 122 CoNG. Rec. $\$ 7326$ (daily ed. May 17, 1976) (reprinting address by Richard Wiley, Chairman of the FCC, before the Int'l Communications Ass'n). Although competitive services may grow in proportion to monopoly services if private-line communications expand as a substitute for long-distance service, any foresecable reduction in the carriers' revenues resulting from competition would not seem to require the drastic realignment of basic phone service rates predicted by Bell.

Moreover, eren if AT\&:T's share of the equipment market has declined, rapid expansion of the entire market has meant higher total revenues from equipment. The market for telecommunications equipment grew by more than $50 \%$ between 1970 and 1975 as a result of competition. Economic Implications, supra note 4 , at 61,137 . As a consequence of this dramatic growth, AT\&:T's 1975 "increase in revenue for private-line and terminal-equipment services ... was more than double the total revenues of all competing suppliers of these services." 122 CoNG. REc. S7327 (daily cd. May 17, 1976).

16. Economic Implications, supra note 4, at 147-48. After examining studies by the carriers and NARUC that found monopoly scrvices supported by surplus equipment revenues, and opposite findings by the New York Public Service Commission staff and the Office of Telecommunications Policy, the FCC concluded that equipment services "are probably recipients of subsidy or contribution from either interstate telephone service or basic local telephone services." Id. at 147. As the FCC acknowledged, however, the studies are a methodological quagmire, often using ill-defined or even contradictory cost-allocation procedures. $I d$. at 123 . The conclusions, therefore, must be regarded as tentative.

47. Baumol, Reasonable Rules for Rate Regulation: Plausible Policies for an Imperfect World, in The Crisis of The Regulatory Commissions 187, 196-200 (P. MacAvoy ed. 1970) (all utility services must be compensatory to achieve efficiency); Lerner, Conflicting Principles of Public Utility Rate Regulation, in id. at 18, 19 (utility prices should equal marginal costs).

48. Without barriers to entry, competitive entry would take place until the price of equipment services equaled the marginal cost of providing them. Scherer, supra note 28 , at 18.19; Posner, supra note 39, at 609 .

49. There may be social or political reasons for providing residential telcphone scrvice below cost (e.g., to encourage interaction among citizens). The decision to subsidize should not be made by a private entity, however, but should be in the hands of a publicly accountable body. 2 A. KAHN, supra note 28 , at $15 \mathrm{I}$. 
under Bell's asserted pricing policy, most of the higher equipment costs for businesses may simply be passed along to consumers in the form of higher prices for other goods. When all businesses face the same inflated costs, they will include as much of that expense in their prices as the demand for their goods permits. ${ }^{50}$ Indeed, if the residential customer would pay more for her phone service without Bell's claimed subsidization, she would probably pay less for other products.

\section{After Telerent}

Telerent upheld the FCC's authority over equipment but acknowledged state jurisdiction over intrastate rates. Within this jurisdictional framework, the decision may prove a Pyrrhic victory for the FCC. The communications common carriers can undermine competition by supporting artificially low prices in the terminal-equipment market with revenues from intrastate monopoly services. ${ }^{.1}$ The carriers can engage in such predatory pricing in competitive markets ${ }^{52}$ because the earnings permitted under regulation are calculated as a percentage rate of return on the operating company's rate base. ${ }^{53}$ To the extent that the regulator permits the carriers to control rates of return on individual services, subject to the overall rate-of-return constraint, the carriers can recoup losses in competitive markets by pricing well above cost in monopoly markets where the demand for services is relatively inelastic. ${ }^{54}$ And under rate-of-return regulation, expansion of the capital base through greater participation in competitive markets-even participation at a loss-can increase the total allowed earnings of the carrier. ${ }^{55}$

50. Cf. P. Samuelson, Economics $387-89$ (9th ed. 1973) (amount of sales tax passed on to consumers depends on responsiveness of demand to changes in price).

51. Trebing, supra note 3, at 327, anticipated such difficulties after Carterfone, predicting that:

[t]he problem will be to prevent extortionate rates in the provision of monopoly services. . . For example, depreciation charges for obsolete plant could be written off against the monopoly sector, while the competitive services enjoy the benefits of new technology through low prices. This would distort the incidence of the costs and benefits of technology. Similarly, prices could be set below long-run marginal cost, thereby permitting the monopoly service to subsidize the efforts of the carrier in highly competitive markets.

See Melody, Interservice Subsidy: Regulatory Standards and Applied Economics, in Essays on Public Utility Pricing and Regulation 167, 205-10 (H. Trebing ed. 1971); Posner, supra note 39 , at 605 .

52. Noll \& Rivlin, Regulating Prices in Competitive Markets, 82 YALE L.J. 1426, 1427 (1972).

53. See note 10 supra.

54. Averch \& Johnson, Behavior of the Firm Under Regulatory Restraint, 52 AM. ECoN. REv. 1052, 1058-59, $1063-66$ (1962); Posner, supra note 39, at 615.

55. Averch \& Johnson, supra note 54, at 1058 , pointed out that if the regulator focuses only on the firm's overall rate of return, the firm

may have an incentive (that it would not have in the absence of regulation) to 
In fact, it has been argued that the common carriers have used monopoly revenues to subsidize product lines in competitive interstate markets. A few months after the FCC's decision in 1959 to permit competition in provision of private microwave transmission systems, ${ }^{56}$ American Telephone \& Telegraph Co. cut prices of competitive services so drastically that the FCC found that it had engaged in unreasonable price discrimination. ${ }^{57}$ On the intrastate level, local telephone operating companies may currently be subsidizing competitive equipment services beyond the reach of the FCC. Analyses of five different Bell company pricing policies in the last few years suggest several possible guises for subsidization of equipment prices, such as absorbing losses in the equipment business without requesting higher rates, ${ }^{5 \mathrm{~s}}$ or cutting or maintaining equipment prices while raising monopoly service charges. ${ }^{50}$ Further, some telephone companies have understated

enter these other markets, even if the cost of so doing exceeds the additional revenues. Expanding into other markets may enable the firm to inflate its rate base .... and permit it to earn a greater total constrained profit than would have been possible in the absence of second markets.

56. Allocation of Frequencies in Bands Above 890 Mcs., 27 F.C.C. 359, 18 RAD. REg. (P-H) 1767 (1959), modified, 29 F.C.C. 825, 20 RAD. REG. (P-H) 1602 (1960).

57. Telpak, 23 F.C.C.2d 606, 19 RAd. REg. (P-H) 2D 381 (1970), aff'd sub nom. AT\&T v. FCC, 449 F.2d 439 (2d Cir. 1971). Kahn has criticized the FCC for failing to articulate the basis of its judgment in Telpak. $1 \mathrm{~A}$. KAHN, supra note 28, at 156-58. He also suggests that if the FCC had used a cost-allocation method based on long-run marginal cost (see pp. 555-58 \& notes 75-77, 88-89 infra), the Commission's analysis might not have indicated that Bell's competitive response permitted subsidization. 1 A. KAHN, supra note 28, at 156-58. See Note, Resale and Sharing of Private Line Communications Services: AT\& $T$ Restriction and FCC Regulation, 61 U. VA. L. REv. 679, 689-92 (1975).

58. The New York State Public Service Commission staff determined that New York Telephone's revenues from the terminal equipment business fell "drastically short" of even recovering capital costs in 1974. Kahn \& Zielinski, Proper Objectives in Telephone Rate Structuring, Pus. Utils. Forr., Apr. 8, 1976, at 20 (discussing New York Tel. Co., No. 26775, slip op. at 75-28 (N.Y. Pub. Serv. Comm'n Oct. 22, 1975)). The commission found that equipment and other nontransmission services earned only a $0.64 \%$ return, while monopoly services earned $5.21 \%$. Industrial Reorganization Hearings, supra note 8, pt. 6, at 4682 (1974) (Yog Varma, N.Y. Pub. Serv. Comm'n). In a recent case the commission considered a special pricing program that included accelerated depreciation for a competitive equipment line, and ruled that if the regulated firm earned less than a $12.45 \%$ return on the scrvice, subsidization would be presumed. New York Tel. Co., 12 PUB. U. ReP. (PUR) 4Th 446, 452-53 (N.Y. Pub. Serv. Comm'n 1975).

59. In 1973, the Illinois Commerce Commission rejected Illinois Bell's proposed rates on the grounds that Bell discriminated in favor of its own equipment by charging more for message service to customer-provided PBXs. Industrial Reorganization Hearings, supra note 8, pt. 6, at 4006-08 (1974) (Commission order regarding Touch-Tone surcharge). A 1973 study discovered increases in message service charges in Washington and Oregon of $17 \%-40 \%$, coupled with equipment rate cuts of from $17 \%-37 \%$. Spievack, Communications Common Carrier Price Competition, in Industrial Reorganization Hearings, supra note 8, pt. 2, at 992, 993-95 (1973). That study, compiled by an attorney representing independent equipment companies, also claimed that an Ohio telephone company provided a nominal substitution of equipment services which saved customers $40 \%$ of the previous rate "without any change, modification or difference in service offered." Id. at 995. Increases in service and interface charges without corresponding rises in equipment rates also were reported in Dallas, Texas. Gabel, Barriers to Entry and Boundaries Between Regulated 
equipment-related costs to justify low rates for equipment services. ${ }^{00}$

The FCC's procompetition policy therefore may founder unless the carriers are prevented from using their position astride monopoly and competitive markets to support anticompetitive equipment prices. ${ }^{01}$ But since most telephone company revenues are derived from intrastate service, ${ }^{62}$ and since equipment rates are within the exclusive province of the state commissions, only the state agencies can detect and deter such subsidization. Yet many state commissions are unconcerned about the potential anticompetitive impact of rate structures. ${ }^{63}$

The state commissions resist the FCC's procompetition policy on the grounds that the current telephone network is satisfactory and should not be tampered with. ${ }^{04}$ Additionally, some state commissions, ex-

and Unregulated Telecommunications Services: The Equipment Market, in Industrial Reorganization Hearings, supra note 8, pt. 6, at 3857, 3862-63 (1974).

A recent New York ruling involving a non-Bell carrier, General Tel. Co., 14 PuB. U. REP. (PUR) 4TH 125 (N.Y. Pub. Serv. Comm'n 1976), denied the carrier's request for $44 \%-48 \%$ increases in service rates coupled with an increase in equipment rates of $11 \%$. The Commission found that the carrier would have to raise its equipment rates by $25 \%$ to "ensure that the burden of any possible PBX revenue deficiency will not be borne by basic service users." Id, at 138 .

60. For example, Pacific Northwest Bell estimated its equipment-maintenance costs at $\$ 453,000$ in a 1973 ratemaking proceeding, but in its annual report to the Oregon Public Utility Commission the firm cited actual maintenance expenses of over SI million. Gabel, supra note 59, at 3865-66. In a 1973 rate request, Michigan Bell used 1973 wage figures to estimate the costs of offering monopoly services, but lower 1970 wage figures to estimate the costs of offering equipment services. $I d$. at 3868 .

61. W. Jones, Interconnection of Customer Owned Equipment with the Telephone Network (Jan. 25, 1973), reprinted in Industrial Reorganization Hearings, supra note 8, pt. 5, at 3813,3819 (1974).

62. In 1974, the common carriers earned \$13.9 billion from toll service, a substantial part of which was intrastate, and $\$ 14.1$ billion from local telephone service. FCC, Statistics of the Common Carriers 20 (1975).

63. In a 1973 rate proceeding, the Oregon Public Utility Commissioner refused to consider a contention that Pacific Northwest Bell's rates permitted subsidization on the grounds that "it is not the Commission's place to determine whether [Pacific Northwest's] pricing policy results in lower rates than its unregulated competitors." Gabel, supra note 59 , at 3866 . Both the Chairman of the Oklahoma Corporation Commission and the head of the Gcorgia Public Service Commission, who was then president of NARUC, have strongly opposed interconnection. Wiggins, A Regulator Looks at Competition, Telerhony, Nov. 12, 1973, at 46; An Interconnect Dialog, Telephony, Aug. 13, 1973 , at 43 .

Some state regulatory agencies, however, including the Illinois and New York commissions, have recognized the anticompetitive potential of subsidization. See notes 58 \& 59 supra. The New York commission recently commented: "We recognize that in determining whether rates are just and reasonable it is pertinent to consider if proposed rates ... may reasonably be expected to be anticompetitive." New York Tel. Co., 12 PuB. U. ReP. (PUR) 4TH 446, 449 (N.Y. Pub. Serv. Comm'n 1975).

The Colorado Public Utilities Commission has initiated a quarterly review of the competitive situation in the equipment market. Mountain States Tel. \& Tel. Co., 13 PUB. U. Rer. (PUR) 4TH 170, 183 (Colo. Pub. Utils. Comm'n 1975). The Commission voiced concern that the monopoly power exercised by Mountain States, a Bell operating company, could enable the firm to "subsidize its competitive offerings from the returns of its monopoly services." $I d$. at 181 .

64. See, e.g., Wiggins, $A$ Regulator Looks at Competition, Trlerhony, Nov. 12, 1973, at 46 (statement of NARUC president). 
tremely wary of any policy that might conceivably raise residential phone rates, have accepted Bell's questionable contention that equipment revenues keep monopoly service rates low..$^{65}$ Further, commissions may be susceptible to pressures from the common carriers to ignore potential subsidization. ${ }^{66}$ Although the political benefits of keeping monopoly telephone rates low arguably might prompt commissions to prevent subsidization, the utilities' political power and their control over the economic information and expertise involved in rate proceedings ${ }^{67}$ make this incentive at best an uncertain line of defense. ${ }^{68}$

Commissions such as North Carolina's and Nebraska's which have openly disagreed with the interconnection policy might simply ignore subsidization problems. Indeed, the phalanx of state regulatory authorities pressing the legal challenge to interconnection suggests that state commission resistance may be a serious stumbling block for the FCC's procompetitive policy. ${ }^{69}$ Furthermore, many state commissions are understaffed and overworked, and therefore capable of only

65. See, e.g., Nebraska Challenge, supra note 15, at 16a (Comm'r Gay, concurring) (espousing carriers' position that competition in terminal equipment "erodes contributions to common costs from other than basic exchange service and if revenue requirements are to be met, rates for basic exchange service would have to be raised"); NARUC Report, supra note 43, at 4487-97 (1974). See pp. 548-49 \& notes 40, 41-46 supra.

66. Representative Wirth of Colorado recently noted: "You don't have to be an astute politician to see that it is easier for the telephone industry to exert pressure on the state PUCs (Public Utility Commissions) than on the Federal Communications Commission ...." Boston Herald Advertiser, Sept. 26, 1976, $\$ 2$, at 32, col. 3. The telephone industry's ability to generate political pressure, even at the federal level, is generally acknowledged. See Bus. WEEK, Mar. 15, 1976, at 82; NAT'L J., July 17, 1976, at 1011; N.Y. Times, June 14,1976 , at 51, col. 7. The oft-noted cross-pollination of personnel between regulator and regulated increases the utilities' sway over the commissions. In 1971, the Executive Secretary, Counsel, and three other employees of the Colorado Public Utility Commission were former officials of one of the state's utilities. Three of the 10 PUC Commissioners in Indiana leaving the agency before 1974 took jobs with utilities in the state. CommoN Cause, Moncy, Secrecy, and State Utility Regulation 18-19 (1976).

67. See notes $70 \& 71$ infra.

68. The commissions' desire to keep residential rates low is most visible in separations disputes (discussed at note 10 supra), but the utilities exert countervailing pressure for higher rates. The most convincing model of regulatory behavior is Professor Hilton's "minimal squawk" theory. Hilton, The Basic Behavior of Regulatory Commissions, in Papers $\&$ Proceedings of the Sfth Annual Meeting of the American Economic Association, 62 Am. Econ. Rev., May 1972, at 47 . Given the nature of rate regulation and the limited tenure of public utility commissioners, Hilton suggests that the agencies take a short-run approach to problems, designed to minimize hostility from the regulated industry, and, secondarily, from the public at large.

69. See North Carolina Utils. Comm'n v. FCC, 537 F.2d 787 (4th Cir. 1976). In the FCC's Telerent proceeding, Telerent Leasing Corp., 45 F.C.C.2d 204, 29 RAD. REg. (P-H) 20 553 (1974), the North Carolina and Nebraska commissions were supported by amicus briefs from 10 other state commissions (Missouri, Georgia, Ohio, Maryland, Michigan, Oregon, Washington, Wyoming, Alabama, and Tennessce), id. at 209 n.8, 29 RAd. REG. (P-H) 2D at $558 \mathrm{n} .8$, the Southeastern Association of Regulatory Utilities Commissioners, and NARUC. Id. at 204, 29 RAD. REG. (P-H) 20 at 553. 
limited oversight of intrastate telephone rates. ${ }^{70}$ The analysis essential for monitoring subsidization demands a level of expertise that many state commissions may lack. ${ }^{71}$

\section{A Proposal}

Although the FCG's jurisdictional claims were sustained by the Telerent court, the procompetition policy underlying them is still in jeopardy. Since the FCC has no authority over intrastate phone rates, it cannot effectively police subsidization in equipment markets. If interconnection is to survive as a national policy, both administrative and legislative intervention are required. To facilitate state monitoring of subsidization, the FCC should convene a federal-state Joint Board which would promulgate guidelines for subsidization review. Also, Congress should give the FCG limited authority to review and disallow state-ordered rate realignments that have an anticompetitive impact. ${ }^{72}$

70. The Council of State Governments reported that in 1976 the state public utilities commissions-charged with supervising electricity, water, and transportation industries as well as communications-employed approximately 7,100 people. Council of State Governments, The BooK of THE STAtes 439 (1976). Figures are not available indicating what proportion of the state regulatory staffs are concerned with communications, but NARUG, Report on UTILITY aNd CaRrier Regulation (1974) provides some insights. The Maine utility commission employed 26 people, four of whom were in the electric and telephone department. Wisconsin had 120 regulatory employees, 15 of whom worked on all "utilities." Only the New York commission had a separate division for communications, with 92 employees.

State commissions have been criticized for delay, incompetence, and procarrier bias. Industrial Reorganization Hearings, supra note 8, pt. 5, at $3735-37$ (1974) (T. Craver, Litton Indus., Inc.). See Nelson, Practical Problems of Marginal-Cost Pricing in Public Enterprises: The United States, in Prices: Issues in Theory, Practice and Public Polick 135, 136 (A. Phillips \& O. Williamson eds. 1967) (commissions have incentives to avoid difficult analytical issues in ratemaking); see generally Trebing, supra note 3 , at 318 (common carriers have upper hand in rate proceedings).

71. See Phillips, The Effectiveness of State Commission Regulation, in A Critioue of Administrative Regulation of Public Utilities 71, 81 (WW. Samuels \& H. Trebing cds. 1972) (need for more and better staffing of state commissions); Troxel, Telephone Regulation in Michigan, in Urility Reculation 141, 150 (W. Shepherd \& T. Gies eds. 1966) (state commissions lack properly trained personnel).

72. A possible alternative policy would require the carriers to set up independent equipment subsidiaries to lease or sell equipment and thereby remove the industry from the sphere of regulation. See Industrial Reorganization Hearings, supra note 8, pt. 5, at 3759-60 (1974) (statement of T. Craver, Litton Indus., Inc.); Irwin, Future Dimensions of Communications Regulation, PuB. UtiLs. ForT., Oct. 7, 1976, at 21-24. The FCC imposed such a requirement when carriers tried to enter the data processing field. See note 4 supra. This approach, however, has possible drawbacks. Because the carriers have operated in equipment markets for many years, separation would entail significant costs (e.g., fragmentation of management, personnel, and equipment facilities) and would sacrifice any economies of integration in the provision of both equipment and monopoly services. Kessler \& Stern, Competition, Contract, and Vertical Integration, 69 Y.1LE L.J. I, 2-10 (1959). Cf. Divestiture Proceedings, supra note 4, at 511 (divestiture a "plunge into the unknown"). 


\section{A. FCC Action}

A federal-state Joint Board ${ }^{73}$ would provide the state commissions with general guidelines, subject to FCC review, for evaluating relationships between costs and rates in both competitive and monopoly sectors. The FCC would follow existing procedures in convening the Board and selecting its members, and the Board could draw on FCG staff and resources. ${ }^{74}$ The guidelines could be based on one of two methods for setting the prices of regulated firms in competitive markets: "full-cost" or "long-run marginal-cost" (LRMC) pricing. ${ }^{75}$ The critical differences between the two pricing methods center on their treatment of common costs, or those costs incurred for the production of more than one product line, ${ }^{76}$ and historical costs, or those

73. See p. 544 \& note 25 supra.

74. The Joint Board would consist of three FCC Commissioners and four state commissioners nominated by NARUC and approved by the FCC. The Chairman of the Joint Board would be designated by the FCC Chairman. 47 U.S.C. $\$ 410$ (c) (Supp. V 1975). A Joint Board has the jurisdiction and powers of an FCC administrative law judge (e.g., to subpoena witnesses, to recommend decisions) under $\S 7(\mathrm{~b})$ of the Administrative Procedure Act, 5 U.S.C. $\$ 556$ (c) (1970). 47 U.S.C. $\$ 410$ (c) (Supp. V 1975).

The FCC's proposed program for certification of all interconnect equipment, see note 5 supra, was first suggested by a Joint Board on interconnection. Proposals for New or Revised Interstate and Foreign Message Toll Tel. Serv. (MTS) and Wide Area Tel. Serv. (WATS), 53 F.C.C.2d 221 (1975).

75. The FCC issued a "Statement of Ratemaking Principles" in 1969, AT\&T, 18 F.C.C.2d 761, 765-69 (1969) (appendix), which acknowledged that fully distributed cost and "long-run incremental cost" (LRIC), are the two dominant ratemaking methodologies. Id. at 766-67. The Commission, however, did not express a preference between the two, and the ambivalence has persisted in recent FCC interstate rate decisions. AT\&T (Long Lines Dep't), 59 F.C.C.2d 671, 689-90, 710-15, 37 Rad. REG. (P-H) 2d 519, 539-40, 561-68 (1976); AT\&T (Hi-Lo), 55 F.C.C.2d 224, 245 (1975).

Bccause of the relative imprecision with which LRIC has been defined by the FCC and academic commentators, this Note focuses on long-run marginal-cost pricing as the alternative to full-cost pricing. Compare Stelzer, Pricing in Regulated Industries, $A$ NotSo-Marginal Problem, in The New Economics of Regulated Industries 112, 120-21 (J. Haring ed. 1968) with Baumol \&. Walton, Full Costing, Competition and Regulatory Practice, 82 YALE L.J. 639, 639 (1973). LRIC was initially proposed as an alternative to pure marginal-cost pricing in decreasing-cost industries, because, in the absence of governmental subsidies, marginal cost will always be below average cost at the relevant rates of output. Thus, total costs will not be recovered. Stelzer, supra, at 117. Use of LRIC as a pricing floor would allow the carrier to cover its average costs, while still permitting demand-sensitive pricing. Id. at 132-33. Additionally, pure marginal-cost pricing requires cvaluation of the cost of an additional unit of output, while in the real world a regulated firm must decide on capital expansion which entails large increases in productive capacity. This "lumpiness" in expansion increases the complexity of marginal-cost pricing. 1 A. KuHN, supra note 28, at 75-77. AT\&T has defined LRIC as "the increase in total costs of investment and expenses which would be incurred by the addition of a particular class or group of services," adding that for any single service, long-run incremental costs "will be equal to the sum of the long run marginal costs of the added units of services." Proposed Findings of Fact and Conclusions of Law on Behalf of the Airline Industry Parties at 41, AT\&:T, 41 F.C.C.2d 593 (1973).

76. I A. KAHs, supra note 28, at 77-78. For operating telephone companies, costs common to both equipment and transmission services would include overhead such as accounting or legal services. 
past capital costs embodied in existing plant..$^{77}$

Full-cost pricing allocates historical and common costs among product lines according to their variable costs or some common physical measure of utilization. ${ }^{78}$ In so doing, full-cost pricing substantially curbs potential subsidization. ${ }^{79}$ It can, however, burden the regulated firm's competitive services with costs unrelated to those services. ${ }^{80}$ For example, a full-cost regime might allocate capital costs on the basis of the proportion of the firm's revenues each service produces, rather than according to the capital actually required to generate each service. The carriers could thus be at a disadvantage in a competitive equipment market, since their prices might reflect some of the capital costs of monopoly services, costs obviously not borne by independent equipment manufacturers. Yet, the procompetition policy behind interconnection is undermined if any class of potential market participants is prevented from competing effectively. ${ }^{81}$

LRMC-which excludes historic capital costs and common costs not incurred directly in the production of the new service ${ }^{82}-$ is particularly useful as a pricing floor for goods in competitive markets. ${ }^{83}$ Under LRMG pricing, the regulated firm may earn less revenue per unit on

77. As a result of traditionally low depreciation rates used in rate calculations, telephone utilities generally carry a high level of historic costs on their books of account. 2 A. KAHN, supra note 28 , at 146,150 .

78. J. BonBRight, supra note 29, at 75-77, 337-68; $1 \mathrm{~A}$. KAHN, supra note 28 , at 150-58.

79. See Noll \& Rivlin, supra note 52, at 1434 .

80. Baumol \& Walton, supra note 75 , at $641-42$.

81. In a recent discussion of rate making for a regulated firm's competitive services, the Colorado Public Utilities Commission stated:

It is the commission's aim to prevent ... cross-subsidization of respondent's competitive services by respondent's monopoly services. However, an equally undesirable pricing mechanism is ... the setting of prices above costs ... . Such prices maintain rates above lowest possible costs and therefore permit survival of inefficient firms.

Mountain States Tel. \&: Tel. Co., 13 Pub. U. ReP. (PUR) 4ta 170, 181 (Colo. Pub. Utils. Comm'n 1975).

AT\&T has complained that the FCC has hamstrung AT\&T's competitive responses in other telecommunications markets. For example, the Commission delayed AT\&.T's use of satellites for private-line communications, Establishment of Domestic CommunicationsSatellite Facilities by Non-Governmental Entities, 35 F.C.C.2d 844, 851-52, 24 RAD. REc. (P-H) 2D 1942, 1950-51 (1972), and also held up AT\&T's entry into data transmission markets. AT\&T, 50 F.C.C.2d 501, 511-12 (1974). Carrier Regulation Hearings, supra note 41 , at 272-74 (statement of Prof. E.V. Rostow).

82. Kahn suggests that a practical pricing rule using LRMC would combine two elements: the short-term average variable costs per unit of sale associated with a large, expected, incremental block of sales and the "estimated additional capital costs per unit, for the additional capacity that will have to be constructed if sales at that price are expected to continue over time or to grow." 1 A. KAHN, supra note 28, at 84-85. Both elements would represent an average over "some period of years extending into the future." $I d$. As Kahn emphasizes, absolute precision in such estimates would require costly data collection, but approximation of LRMC should produce valuable efficiency gains. See id. at 86.

83. Id. at 142-43, 158; Stelzer, supra note 75, at 121. 
its competitive lines than it would with full-cost pricing. But if demand for the competitive goods is sufficiently elastic-that is, if demand increases substantially in response to a decrease in price ${ }^{84}-$ the higher volume of business should increase the firm's net revenues. ${ }^{85}$ Thus, earnings are generated to apply to common and historic costs that would probably be borne solely by monopoly customers if the regulated firm were required to employ full-cost pricing in its competitive markets. ${ }^{86}$ With LRMC pricing, the regulated firm enters competitive markets without an overhang of capital costs from its monopoly business. And by including in its price those capital and variable expenses directly incurred in the production and merchandising of terminal equipment, LRMC pricing should limit subsidization. ${ }^{87}$ The resulting rate structure should parallel that of any new entrant in the market. ${ }^{88}$

Admittedly, LRMC pricing is more complicated than full-cost pricing, requiring regulators to evaluate carefully the utility's cost allocations service by service. ${ }^{89}$ Implementation of LRMC pricing also

84. P. SAmulson, supra note 50 , at $379-80$.

85. 2 A. KAHN, supra note 28, at 137-42; Stelzer, supra note 75, at 121.

86. Baumol, Eckstein \& Kahn, supra note 8 , at 1344-45, 1348-49, suggests that in order to determine whether a service is compensatory the regulator should simply evaluate the impact on the firm of termination of the service. If rates on remaining services would have to be adjusted upward, the service is not a burden on other customers.

87. See I A. KAHN, supra note 28 , at 85 .

88. The contrast between full-cost pricing and LRMG pricing can be illustrated with an example adapted from Baumol \& Walton, supra note 75, at $640-41$. Assume that the Gong Telephone Company will incur costs of $\$ 20$ million if it provides message transmission service $(M I)$ to its monopoly customers, or costs of $\$ 10$ million if it offers equipment services $(E)$ in competitive markets. If Gong provides both $M$ and $E$, however, the total costs will be $\$ 25$ million. Thus, the long-run marginal cost of offering $M$, if $E$ is already being produced, is $\$ 15$ million, while the LRMC for $E$ is $\$ 5$ million if $M$ is already being offered. The combined LRMCs for $M$ and $E$ are only $\$ 20$ million, $\$ 5$ million less than total production costs of $\$ 25$ million.

If Gong uses full-cost pricing, the $\$ 5$ million of common costs will be divided by some arbitrary method. For example, if common costs are apportioned according to the ratio of the LRMCs of each service $(15 / 5)$, Gong will have to recover $\$ 6.25$ million from. its sales of $E$, and $\$ 18.75$ million from sales of $M$.

But if consumers of $E$, which is a competitive service, will not pay more than, say, $\$ 5.5$ million for it, then Gong would be unable to remain in the equipment business, and the cost of $M$ would rise to $\$ 20$ million. If Gong will lower its price for $E$ to $\$ 5.5$ million, however, it can remain in the market for $E$, and consumers of $M$ will have to pay only $\$ 19.5$ million. Thus, so long as Gong's LRMC for equipment is recovered, pricing $E$ below full cost will benefit monopoly consumers. By recovering its LRMC on $E$, with common costs absorbed by the product line with lower demand elasticity, Gong follows the pricing policy of a competitive firm.

89. Stelzer, supra note 75, at 133-35; Noll \& Rivlin, supra note 52, at 1429. The relative simplicity of full-cost calculations has commended the method to most regulatory agencies. Id. at 1432.

LRMC calculations would require breakdowns of capital and operating expenses according to product line, information not generally available in the industry. See note 92 infra. The regulator must combine cost data with demand projection estimates to 
relies on demand estimates that, like the cost-allocation estimates, cannot always be made with great precision..$^{90}$ But by promoting competition in the multibillion dollar equipment industry, use of LRMC as a pricing floor would generate benefits that can reasonably be expected to outweigh the increased administrative costs.91 Further, the Joint Board can minimize that increase by reducing the principles of LRMG pricing to operational terms accessible to the state commissions. ${ }^{92}$

\section{B. Legislation}

Congress should amend the Communications Act to provide for ultimate FCC review of the competitive impact of rate realignments approved by state commissions. ${ }^{93}$ Such federal review would furnish the common carriers and the state commissions with a strong incentive to implement an LRMG standard and avoid subsidization. In addition, it would be consonant with traditional federal responsibility for promoting competition in national industries ${ }^{94}$ and would fulfill that

gauge the future capital requirements of the competitive service. See note 82 supra. The regulator can then determine whether the price for a competitive service covers its LRMC. Baumol, Eckstein \& Kahn, supra note 8, at 1348-49.

90. Stelzer, supra note 75 , at 133 .

91. For 1974 the state utility commissions spent about $\$ 130$ million to regulate electric, gas, water, communications, and sewer utilities, cable television, railroad, trucking, and bus concerns. NARUC, REPORT ON UTILITY AND CARRIER Regulation 584 (1974). In the same year, the carriers purchased more than $\$ 1.5$ billion of terminal equipment, a figure that excludes sales by competitive equipment suppliers. FCC, STatistics of THE Common CARRIERS 21 (1975). One can reasonably predict that the benefits of lower prices, greater product variety, and increased technological ferment in the equipment industry will exceed the possible added costs to the states of reviewing rates for subsidization.

92. Efforts have been made to translate LRMC pricing into practical guidelines. Stelzer, supra note 75, at 133-35; note 82 supra. AT\&T has much experience with LRMC calculations, having submitted extensive studies of incremental-cost pricing in FCC rate cases. See, e.g., AT\&T (Hi-Lo), 55 F.C.C.2d 224, 232-38 (1975).

The state commissions would not be bound by the Joint Board guidelines, 47 C.F.R. ch. 1, app. A at 231 (1975), but the FCC subsidization review proposed at pp. 558-60 infra would militate strongly for their adoption.

A critical step to facilitate state subsidization review would be revamping the Uniform System of Accounts prescribed for the common carriers by the FCC, 47 C.F.R. $\$ \S 31,33$ (1975), to ensure that, to the greatest extent possible, carriers record costs according to product line. The System of Accounts has not been significantly revised since 1935, Divestiture Proceedings, supra note 4, at 399, 516-17, and the failings of the current accounting system have hampered the FCC's attempts to detect subsidization in privateline services. AT\&T (Long Lines Dep't), 59 F.C.C.2d 671, 703-10, 37 RAD. REG. (P-H) 2D 519, 553-60 (1976). A more informative accounting system with more refined cost allocations would greatly aid regulators by providing a useful data base for calculation of LRMC. The carriers' accounting practices would still have to be monitored, but the regulatory burden would be lighter.

93. The legislation would amend Title II of the Communications Act of 1934, 47 U.S.C. $\$ \S 201-223$ (1970 \& Supp. V 1975).

94. Since passage of the Sherman Act in 1890, 15 U.S.C. $\$ \$ 1-7$ (1970 \& Supp. V 1975), the federal government has assumed the burden of enforcing procompetition policies. Such policies have often taken primacy over regulatory schemes. See Otter Tail Power Co. v. United States, 410 U.S. 366 (1973) (local electric utility subject to Sherman Act 
responsibility with only limited intrusion on the prerogatives of state regulatory commissions. ${ }^{05}$

The procedures of the FCC review would be straightforward. Acting on its own initiative, the FCC would have 30 days after a state rate decision to determine that there was a prima facie case that the approved rate structure permitted subsidization. ${ }^{96}$ Upon such a preliminary finding the FCC would undertake a broader investigation of revenues and costs for competitive and monopoly services. ${ }^{97}$ During this inquiry the proposed rates would not go into effect, but the FCC would gauge its workload so that investigations in all but extraordinary cases would not exceed 180 days. ${ }^{98}$ In the course of a full-scale investigation, the FCC could, if necessary, reopen the record

notwithstanding regulation by Federal Power Commission); United States v. Philadelphia Nat'l Bank, 374 U.S. 321 (1963) (bank merger subject to Clayton Act notwithstanding regulation by banking agencies under Bank Merger Act).

In the narrower context of the FCC, the courts have acknowledged the Commission's duty to encourage competition in communications when it is in the public interest. FCC v. RCA Communications, Inc., 346 U.S. 86, 96-97 (1953).

95. The review procedure proposed here does not present significant Tenth Amendment problems. This congressionally-mandated discretionary review is analogous to, though more limited than, powers held by the ICC under $\S 13(4)$ of the Interstate Commerce Act, 49 U.S.C. $\$ 13(4)(1970)$ (authorizing ICC to set aside rates made by state commission if such rates discriminate against interstate commerce). The courts have upheld $\S 13(4)$ as a valid exercise of congressional power under the commerce clause. Louisiana Pub. Serv. Comm'n v. Texas \& N.O.R.R., 284 U.S. 125, 130-31 (1931); Florida v. United States, 282 U.S. 194, $210-11$ (1931); Wisconsin R.R. Comm'n v. Chicago, B \& Q.R.R., 257 U.S. 563, 586-88 (1922).

Despite its reliance on statutory grounds for resolving Brown v. EPA, 521 F.2d 827 (9th Cir. 1975), cert. granted, 96 S. Ct. 2224 (1976), the Ninth Circuit suggested that there might be constitutional objections to a federal agency's imposition of affirmative obligations on state agencies. The court held that under $\S 110(c)$ of the National Environmental Protection Act, 42 U.S.C. $\$ 1857 c-5$ (Supp. V 1975), the EPA could not force California to fight air pollution through several elaborate programs. $521 \mathrm{~F} .2 \mathrm{~d}$ at 830 . The instant proposal is distinguishable from the procedure struck down in the Brown case on two grounds. First, the proposal does not create a new range of affirmative duties for the state, which the FCC would enforce, but rather limits the manner in which the states can carry out their current ratemaking responsibilities (i.e., they are not to approve anticompetitive rates). This limitation hardly represents a devouring of the "'essentials of state sovereignty:" "National League of Cities v. Usery, 96 S. Ct. 2465, 2476 (1976) (citing Maryland v. Wirtz, 392 U.S. 183, 205 (1968) (Douglas, J., dissenting)). Second, the burden placed on the states under this Note's proposal in terms of costs and displacement of state policy choices is not comparable to that imposed by the wide-ranging antipollution program prescribed in Brown, or to the burden imposed by application of the federal minimum wage requirement to state employees at issue in Usery.

96. Such a case might be established if there were rate reductions for competitive services coupled with higher monopoly rates, or if there were recurring losses in competitive services.

97. The carriers would presumably refrain from changing their rates during the 30 day review period in order to avoid the administrative costs of an FCC stay of the new rates. The FCC's failure to act within 30 days would constitute a waiver of the authority to review.

98. Since the state commissions usually take several months to review a rate request, further extension of the ratemaking process should be avoided unless necessary. Nevertheless, the threat of delayed rate increases pending FCC review should provide additional incentives to the carriers to refrain from subsidization. 
of the rate proceeding. If the Commission concluded that the rates under study permitted subsidization, it would disallow those rates. That decision would be subject to judicial review, ${ }^{92}$ but since a finding of subsidization would be one of fact, the courts would accord deference to the Commission's determination. ${ }^{100}$ The state commissions would have responsibility for recalculating the rates to prevent subsidization. ${ }^{101}$

Since state commissions are currently deluged with proposed rate revisions, ${ }^{102}$ detailed FCC subsidization review of all rate cases would require geometric expansion of the FCC Common Carrier Bureau. ${ }^{103}$ The state commissions-assisted by Joint Board guidelines-must therefore play an active role in monitoring subsidization. Still, discretionary FCC review would detect the more blatant subsidization and, perhaps more importantly, would deter operating companies from undertaking subsidization and state commissions from ignoring it. The federal commission's enforcement of the review program would be structured to generate maximum deterrent effect with the minimum expenditure of resources. Framed in these terms, this proposal would require some expansion of the Common Carrier Bureau, but not so great an increase as to eclipse the benefits of competition.

\section{Conclusion}

The proposal advanced here would achieve the most effective limits on subsidization within the least burdensome regulatory framework. It would maximize the effectiveness of state commission rate reviews as well as the deterrent impact of FCC review. The irony of prescribing greater regulatory effort to ensure effective competition is inescapable, but in view of the benefits of competition in the equipment industry, such effort is appropriate.

99. Administrative Procedure Act $\S 10,5$ U.S.C. $\S \S 701-706$ (1970).

100. Agency determinations of fact are subject to reversal only if found to be "arbitrary and capricious" or "unsupported by substantial evidence." 5 U.S.C. $\$ 706(2)(A)$, (E) (1970). In these determinations, "[t]he court is not empowered to substitute its judgment for that of the agency." Citizens to Preserve Overton Park, Inc. v. Volpe, 401 U.S. 402,416 (1971).

101. The proposal in this Note is designed to ensure state commission participation in monitoring of subsidization. But if a state commission refused to reset rates that the FCC disallowed, or demonstrated bad faith in the procedure, the FCC could obtain injunctive relief against the state agency.

102. The Bell System alone won 32 rate increases in the first eight months of 1976, and Bell rate requests were still pending in 26 states in September. Wall St. J., Sept. 16, 1976 , at 3 , col. 1 .

103. As of late 1975, the Common Carrier Bureau had a staff of 220 . Hearings on Regulatory Reform Before Senate Comm. on Government Operations, 94th Cong., Ist Sess. 84 (1975) (Sen. Metcalf). Its budget for 1976-1977 was approximately $\$ 7$ million. The Budget of the United States Government, Fiscal Year 1977, at 723-24. 